\title{
Quantifying spatial and temporal discharge dynamics of an event in a first order stream, using distributed temperature sensing
}

\author{
M. C. Westhoff ${ }^{1}$, T. A. Bogaard ${ }^{1,2}$, and H. H. G. Savenije ${ }^{1}$ \\ ${ }^{1}$ Water Resources Section, Faculty of Civil Engineering and Geosciences, Delft University of Technology, P.O. Box 5048, \\ 2600 GA Delft, The Netherlands \\ ${ }^{2}$ Centre de Recherche Public Gabriel Lippmann, Department Environment and Agro-Biotechnologies, 4422 Belvaux, \\ Grand-Duchy of Luxembourg
}

Received: 25 February 2011 - Published in Hydrol. Earth Syst. Sci. Discuss.: 1 March 2011

Revised: 16 June 2011 - Accepted: 17 June 2011 - Published: 24 June 2011

\begin{abstract}
Understanding the spatial distribution of discharge can be important for water quality and quantity modeling. Non-steady flood waves can, particularly as a result of short high intensity summer rainstorms, influence small headwater streams significantly. The aim of this paper is to quantify the spatial and temporal dynamics of stream flow in a headwater stream during a summer rainstorm. These dynamics include gains and losses of stream water, the effect of bypasses that become active and hyporheic exchange fluxes that may vary over time as a function of discharge. We use an advectiondispersion model coupled with an energy balance model to simulate in-stream water temperature, which we compare with high resolution temperature observations obtained with Distributed Temperature Sensing. This model was used as a learning tool to stepwise unravel the complex puzzle of instream processes subject to varying discharge. Hypotheses were tested and rejected, which led to more insight in the spatial and temporal dynamics in discharge and hyporheic exchange processes. We showed that, for the studied stream infiltration losses increase during a small rain event, while gains of water remained constant over time. We conclude that, eventually, part of the stream water bypassed the main channel during peak discharge. It also seems that hyporheic exchange varies with varying discharge in the first $250 \mathrm{~m}$ of the stream; while further downstream it remains constant. Because we relied on solar radiation as the main energy input, we were only able to apply this method during a small summer storm and low flow conditions. However, when additional (artificial) energy is available, the presented method is also applicable in larger streams, during higher flow conditions or longer storms.
\end{abstract}

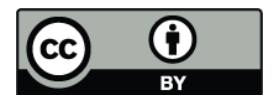

Correspondence to: M. C. Westhoff (m.c.westhoff@tudelft.nl)

\section{Introduction}

Understanding discharge generation processes in headwater catchments is crucial for water quality and quantity modeling (Bonell, 1998). However, it is often difficult to differentiate between different runoff generation processes. A classical way to do this is by hydrograph separation using endmember mixing analysis approach (Sklash and Farvolden, 1979). This technique can be useful in differentiating between different source areas or between event and pre-event water (Uhlenbrook and Hoeg, 2003). However, the spatial resolution is often low, fluxes are lumped and uncertainties can be high.

Understanding the spatial distribution of discharge can be important since non-steady flood waves can influence small headwater streams significantly, particularly as a result of short high intensity summer rainstorms. During such events, discharge can more than double, and side channels can become active. Also subsurface storm flow may occur, although a certain storage threshold in the hillslope has to be passed before this mechanism becomes active (e.g. Trompvan Meerveld and McDonnell, 2006).

To observe the spatial and temporal distribution of lateral inflows, several researchers excavated trenches (Woods and Rowe, 1996; Weiler et al., 1998; Uchida et al., 2005; Retter et al., 2006; Gomi et al., 2008; Tromp-van Meerveld et al., 2008). Although these were able to give spatial and temporal flow information, installation of trenches is destructive and limited in size (2-60 m).

Another approach was presented by Ragan (1968). He monitored all incoming water fluxes in a $190 \mathrm{~m}$ long stretch, including the change of in-stream storage. He added one term to close the water balance, which he concluded to be subsurface stormflow. Although he is one among some others (e.g. Anderson and Burt, 1978; Hjelmfelt Jr. and Burwell, 1984) who gained insights in temporal and spatial

Published by Copernicus Publications on behalf of the European Geosciences Union. 
dynamics of lateral inflow without the use of trenches or 3-D groundwater-surface water models, he did not include infiltration losses of stream water or hyporheic exchange in his analysis while also the location of the calibrated subsurface stormflow was unknown.

Stream water losses (or downwelling fluxes) are difficult to quantify, since they do not influence stream water quality directly. To determine these fluxes, some researchers observed vertical subsurface temperature profiles, which, when coupled with a vertical advection-dispersion model gave flow rates and directions (Stallman, 1965; Lapham, 1989; Taniguchi and Sharma, 1990; Silliman et al., 1995; Constantz and Thomas, 1996; Constantz, 1998; Constantz et al., 2003; Becker et al., 2004; Niswonger et al., 2005; Blasch et al., 2007). However, these profiles were point measurements along the stream and obtained during steady state discharge conditions.

Moreover, hyporheic exchange fluxes may change with varying discharge. This triggered research on seasonal changes in hyporheic exchange, determined from head differences in a vertical profile using piezometer nests (Harvey and Bencala, 1993; Wroblicky et al., 1998; Bartolino, 2003). In addition, on the timescale of one flood wave, coupled 3-D groundwater-surface water models were developed (Lal, 2001; Habel and Bagtzoglou, 2005; Boano et al., 2007; Ha et al., 2008). However, these deterministic models require an accurate description of hydraulic conductivities and bedforms while such data are often not available. To overcome this problem, hyporheic exchange has been quantified using in-stream tracer tests. Most studies linking hyporheic exchange with discharge did their tracer tests during different discharge regimes (Legrand-Marcq and Laudelout, 1985; Harvey et al., 1996; Morrice et al., 1997; Wörman and Wachniew, 2007; Zarnetske et al., 2007; Schmid, 2008; Schmid et al., 2010), different morphological states (Hart et al., 1999; Harvey et al., 2003) or between different streams (D'angelo et al., 1993; Morrice et al., 1997; Schmid et al., 2010), but always during steady state flow conditions and not during a complete rainstorm.

The aim of this paper is to quantify the spatial and temporal dynamics of stream flow in a headwater catchment during a summer rainstorm. These dynamics include gains and losses of stream water, the effect of bypasses (in our case a side channel of ca $20 \mathrm{~m}$ long) that become active and hyporheic exchange fluxes that may vary over time as a function of discharge. In a previous study we showed the relation between hydraulics, in-stream temperature and hyporheic exchange in a first order stream during steady state discharge conditions (Westhoff et al., 2011). In this paper we focus on the dynamic effects that occur during and after a small intensive summer rainstorm of $6.4 \mathrm{~mm}$, with a maximum intensity of $4.8 \mathrm{~mm}$ in $10 \mathrm{~min}$. We use an advection-dispersion model coupled with an energy balance model to simulate instream water temperature, which we compare with high resolution temperature observations obtained with Distributed

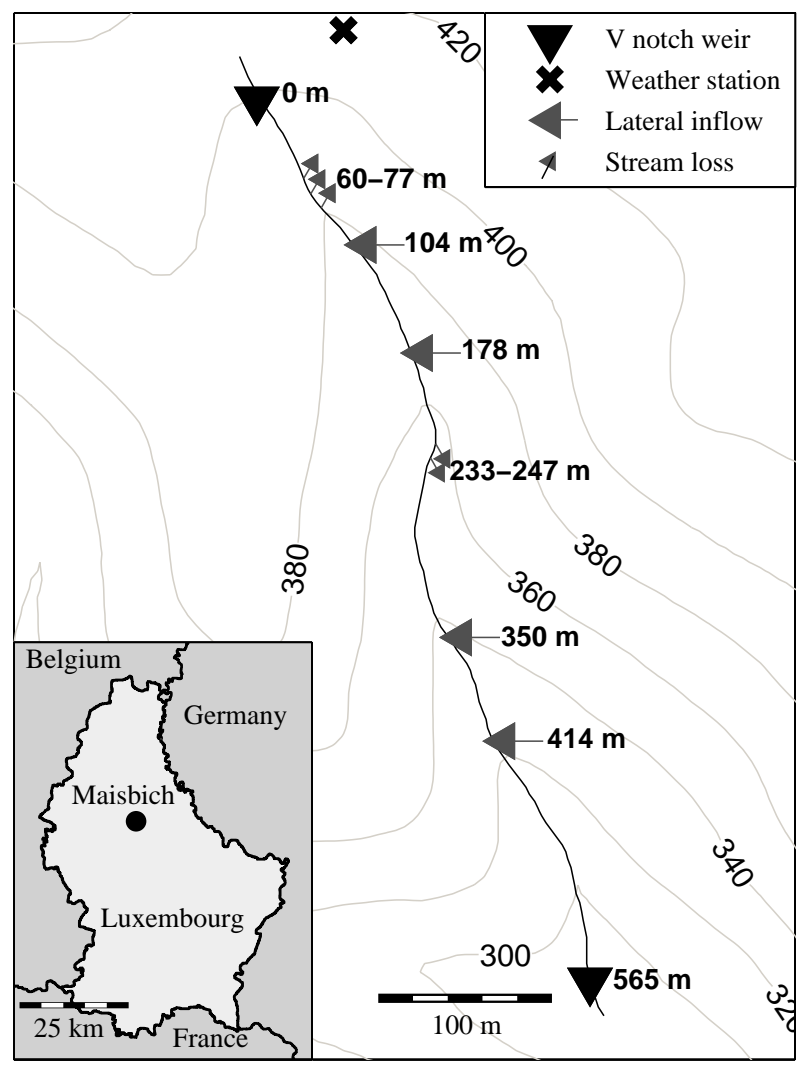

Fig. 1. Map of the studied stretch of the Maisbich. The isohypse show the altitude above mean sea level. Distances of the lateral inand outflows are distances from the upstream V-notch weir measured along the stream.

Temperature Sensing (DTS). Together with upstream and downstream discharge observations, we were able to locate and estimate the dynamics of hyporheic exchange, lateral inflows and bypasses. We used the method as a learning tool in which we stepwise unravel the complex interactions and dynamics in discharge.

\section{Site description and measurements}

\subsection{Site description}

This research took place in a $565 \mathrm{~m}$ long reach of the Maisbich: a first order stream in central Luxembourg $\left(49^{\circ} 53^{\prime} \mathrm{N}\right.$ and $\left.6^{\circ} 02^{\prime} \mathrm{E}\right)$. The investigated branch drains an area of $0.34 \mathrm{~km}^{2}$. The stream has an average slope of $18 \%$, with on both sides steep forested hillslopes with slopes varying between 25 and $50 \%$ (Fig. 1).

In the whole catchment, the schist bedrock is covered with a layer of regolith consisting of fractured and weathered rock of a few meters thick and varying clay content. In the riparian zone and at the foot of the hillslopes, thin colluvial and alluvial deposits of $<1 \mathrm{~m}$ thick are found. The headwater stream 
originates in a small depression below the convex transition of plateau to hillslope. The steep stream scoured the soil layer up to the fractured rock, creating at many places steep banks of $0.2-1 \mathrm{~m}$ high. The streambed is rough with many in-stream rock clasts. Summer storm flows are characterized by a double peak: the first peak is mainly caused by "rain on water" and rain on the saturated riparian zone (saturation overland flow), while the second peak is assumed to be subsurface storm flow (Fig. 2).

Along the stream, 4 distinct lateral, partly submerged inflows are present at 104, 178, 350 and $414 \mathrm{~m}$ from the upstream V-notch weir, respectively. These inflows generally are cracks in the underlying bedrock from where water seeps to the stream. Two smaller inflows enter the stream at 383 and $393 \mathrm{~m}$, but they are $<5 \%$ of the discharge directly downstream of the inflow, and too small to monitor. During the studied period (22 and 23 June 2008), two areas of stream water loss were identified: one area between 60 and $77 \mathrm{~m}$ where $\sim 95 \%$ of water infiltrates into the subsurface and a smaller one between 233 and $247 \mathrm{~m}$ where $\sim 45 \%$ of the water infiltrates. In-stream salt injection tests during previous field campaigns with similar discharge regimes as this study demonstrated that at least part of the water that infiltrates between 60 and $77 \mathrm{~m}$ returns to the stream at $104 \mathrm{~m}$ (data not shown). A previous study by Westhoff et al. (2011) showed that at many places along the stream small scale $(\sim$ m) hyporheic exchange is present (see Sect. 3.1).

\subsection{Measurements}

Two V-notch weirs are present at the upstream and downstream end of the studied stream reach. They have been equipped with pressure loggers (Keller DCX22), monitoring water levels at $10 \mathrm{~min}$ intervals. During the studied period, the pre-event discharge was 0.44 and $0.621 \mathrm{~s}^{-1}$ for the upstream and downstream V-notch weir, respectively. Peak discharge was 1.9 and $1.81 \mathrm{~s}^{-1}$ (Fig. 2).

Along the entire stream, temperature was measured with a DTS system (Halo, Sensornet, UK). The system gives an integrated temperature for each $2 \mathrm{~m}$ along a fiber optic cable which is averaged over $3 \mathrm{~min}$. The precision, using these settings, is $\sim 0.1^{\circ} \mathrm{C}$. Comparison with independent temperature loggers (TidbiT v2 Temp logger, HOBO, USA) at 12, 176 and $347 \mathrm{~m}$ gave a Root Mean Square Error (RMSE) of $0.27{ }^{\circ} \mathrm{C}$ (for a more detailed description about DTS see, Selker et al., 2006a,b; Tyler et al., 2009).

The water temperature of each of the 4 distinct sources was measured with independent temperature loggers (TidbiT v2 Temp logger, HOBO, USA) at a 6 min interval. At the 3 most upstream inflows, the stream water temperature just upstream and downstream of the inflow was also measured with TidbiT temperature loggers.

In the meadow just uphill of the upper V-notch weir, a HOBO weather station was installed, measuring incoming solar radiation, air temperature, air pressure, wind speed and

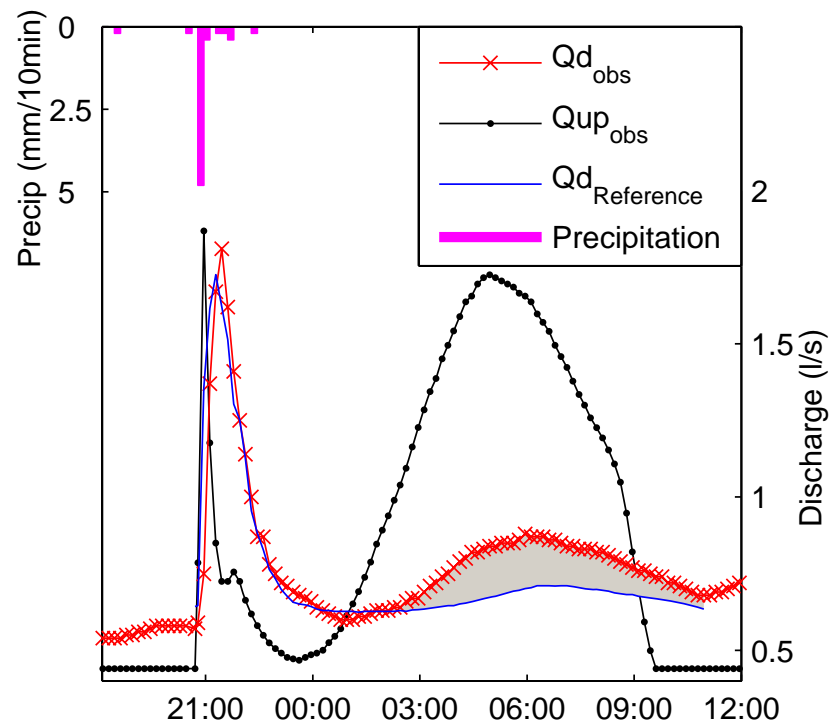

Fig. 2. Observed and simulated discharge of second peak on 22 and 23 June 2008, using the same parameters as during the first discharge peak. The subscripts $d$ and up refer to downstream and upstream. The shaded area is the difference between observed and simulated discharge.

wind direction. Relative humidity was measured in Ettelbruck ( $\sim 6 \mathrm{~km}$ from the site) by the Administration des Services Techniques de l'Agriculture (http://www.asta.etat.lu), with a temporal resolution of $10 \mathrm{~min}$.

At 64 places along the stream, cross-sectional riverbed profiles were measured using a pin-meter (Westhoff et al., 2011). The pins were situated $2 \mathrm{~cm}$ from each other. The vertical displacement of each pin could be determined with an accuracy of $\sim 2 \mathrm{~mm}$. To distinguish between in-stream rock clasts and the riverbed, we drew a contour around the lower pins. These measurements allowed us to link water level directly to cross-sectional area of stream water, crosssectional area of rock clasts, wetted perimeter, and surface width of the stream, which are all parameters needed in the model framework.

\section{Methods}

\subsection{Previous work and model description}

This study builds on previous work by Westhoff et al. (2011). They developed and calibrated a temperature model for the same stream as this study. This is a 1-D advection-dispersion model for heat transport with 2 transient storage zones coupled with an energy balance model. One transient storage zone represents heat exchange with in-stream rock clasts, which Westhoff et al. (2010) found to be an important heat buffer. The second transient storage zone represents the hyporheic zone and is assumed to be located below the stream 

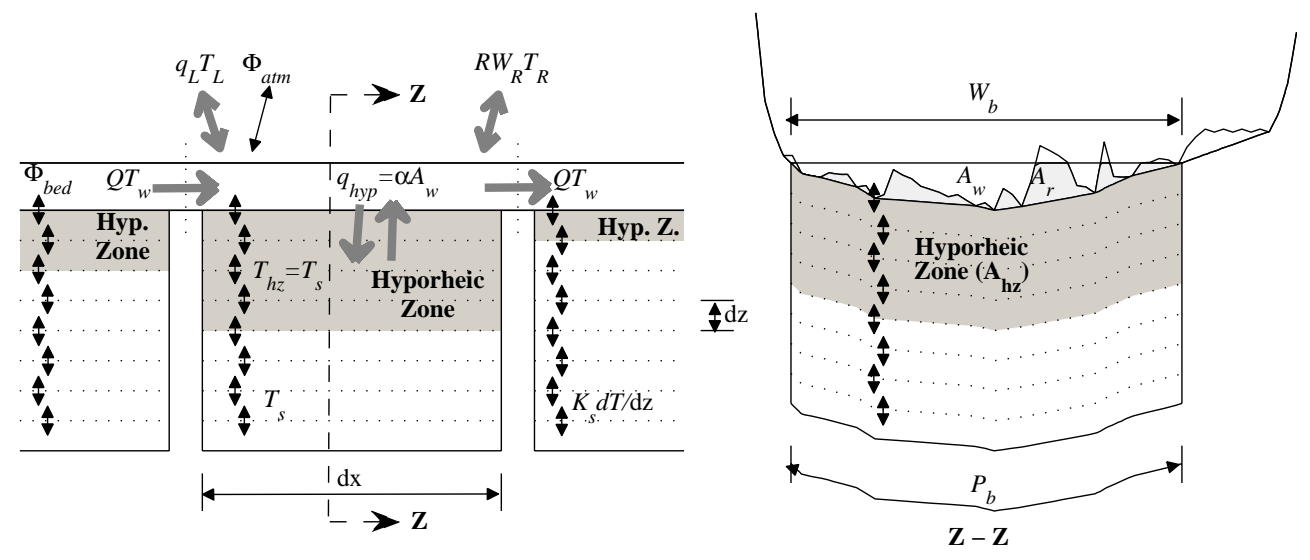

Fig. 3. Schematic of the 1-D advection-dispersion model with transient storage. The grey arrows are water fluxes, the black arrows are energy fluxes. $q_{\text {hyp }}$ is the hyporheic exchange flux per unit stream length, given by $\alpha A_{\mathrm{W}}$. The cross-sectional area of water and rock clasts is given by $A_{\mathrm{b}}=A_{\mathrm{W}}+A_{\mathrm{r}}$, where $A_{\mathrm{r}}$ is the cross-sectional area of the rock clasts. (Figure is adapted from Westhoff et al., 2011)

in the regolith. Hyporheic exchange (both upwelling and downwelling) was assumed to take place within a single longitudinal grid cell, and lateral hyporheic flow paths are not taken into account. The temperature of the hyporheic zone was derived by simulating the temperature of the subsurface to a depth of $1 \mathrm{~m}$, while the hyporheic exchange rate and the size of the hyporheic zone were determined by calibration. Westhoff et al. (2011) used this model to locate and quantify hyporheic exchange with a resolution of 2 to $10 \mathrm{~m}$ during steady state discharge conditions, resulting in spatial variable hyporheic exchange parameters. A conceptual sketch of this model is shown in Fig. 3 (the same symbols are used as in Eqs. (1)-(4)). After calibration, Westhoff et al. (2011) ended up with 13 different stream segments, varying between 9 and $100 \mathrm{~m}$, with constant hyporheic exchange parameters.

In this study we coupled this model with a dynamic routing model, which is needed to simulate in-stream temperature during non-steady flood waves. The governing equations for this dynamic routing and temperature model are:

$$
\begin{aligned}
& \frac{\partial A_{\mathrm{w}}}{\partial t}+\frac{\partial Q}{\partial x}=q_{\mathrm{L}}+R W_{\mathrm{R}} \\
& \frac{\partial u}{\partial t}+g \frac{\partial \zeta}{\partial x}+u \frac{\partial u}{\partial x}+C_{\mathrm{f}} \frac{u|u|}{R_{\mathrm{h}}}=0
\end{aligned}
$$

$\rho_{\mathrm{w}} c_{\mathrm{w}} \frac{\partial A_{\mathrm{w}} T_{\mathrm{w}}}{\partial t}+\rho_{\mathrm{r}} c_{\mathrm{r}} \frac{\partial A_{\mathrm{r}} T_{\mathrm{r}}}{\partial t}+\rho_{\mathrm{w}} c_{\mathrm{w}} \frac{\partial Q T_{\mathrm{w}}}{\partial x}+\rho_{\mathrm{w}} c_{\mathrm{w}} \frac{\partial}{\partial x}$

$\left(-A_{\mathrm{w}} D \frac{\partial T_{\mathrm{w}}}{\partial x}\right)=\rho_{\mathrm{w}} c_{\mathrm{w}}\left(q_{\mathrm{L}} T_{\mathrm{L}}+R W_{\mathrm{R}} T_{\mathrm{R}}\right)$

$+\rho_{\mathrm{w}} c_{\mathrm{w}} \alpha A_{\mathrm{w}}\left(T_{\mathrm{hz}}-T_{\mathrm{w}}\right)+W_{\mathrm{b}} \Phi_{\mathrm{atm}}+P_{\mathrm{b}} \Phi_{\mathrm{bed}}$

$\frac{\partial T_{\mathrm{s}}}{\partial t}=-K_{\mathrm{s}} \frac{\partial^{2} T_{\mathrm{s}}}{\partial z^{2}}+\alpha \frac{A_{\mathrm{w}}}{A_{\mathrm{hz}}}\left(T_{\mathrm{w}}-T_{\mathrm{hz}}\right)-\frac{\Phi_{\mathrm{bed}}}{c_{\mathrm{b}} \rho_{\mathrm{b}} \partial z}$

where $Q, u$ and $\zeta$ are the discharge $\left[\mathrm{m}^{3} \mathrm{~s}^{-1}\right]$, stream velocity $\left[\mathrm{ms}^{-1}\right]$ and water level $[\mathrm{m}] . \quad A$ and $T$ are the cross- sectional area $\left[\mathrm{m}^{2}\right]$ and temperature $\left[{ }^{\circ} \mathrm{C}\right], R$ is the precipitation $\left[\mathrm{ms}^{-1}\right], W_{\mathrm{R}}$ is the width at which the precipitation turns immediately into runoff $[\mathrm{m}]\left(W_{\mathrm{R}} \geq W_{\mathrm{b}}\right)$ and $T_{\mathrm{R}}$ is the temperature of the precipitation $\left[{ }^{\circ} \mathrm{C}\right] . q_{\mathrm{L}}$ is the lateral inflow per unit stream length $\left[\mathrm{m}^{2} \mathrm{~s}^{-1}\right], g$ is the acceleration of gravity $\left[\mathrm{ms}^{-2}\right], C_{\mathrm{f}}$ is the hydraulic friction of the streambed [-] and $R_{\mathrm{h}}$ is the hydraulic radius [m]. $\rho$ and $c$ are the density $\left[\mathrm{kgm}^{-3}\right]$ and heat capacity $\left[\mathrm{Jkg}^{-1}{ }^{\circ} \mathrm{C}^{-1}\right], D$ is the longitudinal dispersion coefficient $\left[\mathrm{m}^{2} \mathrm{~s}^{-1}\right], \alpha$ is the hyporheic exchange coefficient $\left[\mathrm{s}^{-1}\right], W_{\mathrm{b}}$ and $P_{\mathrm{b}}$ are the width $[\mathrm{m}]$ and the wetted perimeter $[\mathrm{m}] . \quad \Phi_{\mathrm{atm}}$ and $\Phi_{\text {bed }}$ are the net energy exchange $\left[\mathrm{Wm}^{-2}\right]$ through the water-air interface and water-streambed interface, respectively and $K_{\mathrm{S}}$ is the thermal diffusivity of the subsurface $\left[\mathrm{m}^{2} \mathrm{~s}^{-1}\right]$, while $t, x$ and $z$ are time [s], distance along the stream $[\mathrm{m}]$ and depth below the stream [m]. The subscripts $w, L, s$ and $h z$ stand for water, lateral inflow, subsurface and hyporheic zone, while $r$ stands for in-stream rock clasts.

Equations (1) and (2) are the mass balance for water and the momentum equation, needed for the routing model. With this model and with the observed cross-sectional riverbed profiles $Q, u, \zeta, A_{\mathrm{w}}, A_{\mathrm{r}}, W_{\mathrm{b}}$ and $P_{\mathrm{b}}$ were determined over space and time. For the pre-event conditions, the relative contribution of the lateral inflows were determined by comparing observed temperature of the inflow with observed temperature just upstream and downstream of this inflow. The losses of water (between 60 and $77 \mathrm{~m}$, and between 233 and $247 \mathrm{~m}$ ) were determined in such a way that the observed upstream discharge plus all inflows minus all losses equals the observed downstream discharge, while these losses were located during several field visits: e.g. during extreme low flow these parts of the stream fell dry.

The advection-dispersion model is represented by Eq. (3). The first two terms on the left-hand side represent storage of heat in water and storage of heat in in-stream rock clasts, while the third and fourth terms represent advection 
and dispersion of heat. The terms on the right hand side represent the heat budgets of lateral inflows and outflows of stream water, hyporheic exchange, energy exchange between the water-air interface and energy exchange between the water-streambed interface, respectively. Westhoff et al. (2011) showed that the exchange between water and rock clasts is fast enough to assume that it is instantaneous, meaning that the temperature of water and in-stream rock clasts is always the same. Using this assumption, Eq. (3) can then be simplified to:

$$
\begin{aligned}
& \rho_{\mathrm{b}} c_{\mathrm{b}} \frac{\partial A_{\mathrm{b}} T_{\mathrm{w}}}{\partial t}+\rho_{\mathrm{w}} c_{\mathrm{w}} \frac{\partial Q T_{\mathrm{w}}}{\partial x}+\rho_{\mathrm{w}} c_{\mathrm{w}} \frac{\partial}{\partial x}\left(-A_{\mathrm{w}} D \frac{\partial T_{\mathrm{w}}}{\partial x}\right) \\
& =\rho_{\mathrm{w}} c_{\mathrm{w}}\left(q_{\mathrm{L}} T_{\mathrm{L}}+R W_{\mathrm{R}} T_{\mathrm{R}}\right)+\rho_{\mathrm{w}} c_{\mathrm{w}} \alpha A_{\mathrm{w}}\left(T_{\mathrm{hz}}-T_{\mathrm{w}}\right)+ \\
& W_{\mathrm{b}} \Phi_{\mathrm{atm}}+P_{\mathrm{b}} \Phi_{\mathrm{bed}}
\end{aligned}
$$

where $A_{\mathrm{b}}$ is the combined cross-sectional area of water and in-stream rock clasts, while $\rho_{\mathrm{b}}$ and $c_{\mathrm{b}}$ are the weighted averages of density and heat capacity of water and in-stream rock clasts.

The net energy exchange between water and atmosphere $\left(\Phi_{\mathrm{atm}}\right)$ is the sum of solar radiation (corrected for shadow effects) and longwave radiation (taken from Westhoff et al., 2007) and latent and sensible heat (taken from Monteith, 1981). The latent heat and sensible heat were taken from Monteith (1981) because periods of $100 \%$ relative humidity were measured.

The change of subsurface temperature is taken as the sum of vertical heat conduction and hyporheic exchange and is described with Eq. (4). The first term on the right-hand side describes the vertical heat conduction, while the second term represents the hyporheic exchange. The latter is only applied for the vertical grid cells were the hyporheic zone is defined. Note that at these locations $T_{\mathrm{hz}}=T_{\mathrm{s}}$ (Fig. 3).

In the numerical solution we defined 25 horizontal subsurface layers with a vertical thickness of $4 \mathrm{~cm}$ each. At the lower boundary (at $1 \mathrm{~m}$ depth) we assumed a constant temperature of $14^{\circ} \mathrm{C}$. The thickness of the hyporheic zone is determined as $d=A_{\mathrm{hz}} / P_{\mathrm{b}}$. The temperature of the hyporheic return flow $\left(T_{\mathrm{hz}}\right)$ is taken as the average temperature of all subsurface grid cells in 1 vertical where hyporheic exchange was determined.

The third term on the right-hand side of Eq. (4) represents a sink/source term removing/adding heat to the subsurface. However, in our model setup $\Phi_{\text {bed }}$ represents shortwave radiation reaching the streambed, and is therefore only applied to the top layer in the numerical scheme.

This model was calibrated for a 2 day period in July 2009, during steady state discharge conditions (upstream and downstream discharge was 0.35 and $0.471 \mathrm{~s}^{-1}$ ) with the aim of assessing hyporheic exchange (Westhoff et al., 2011). For this study, we first validated the model for a 2 day period prior to a rainfall event at 22 June 2008, 20:40 GMT+1, during which the discharge was steady, with upstream and downstream discharge of 0.44 and $0.621 \mathrm{~s}^{-1}$. The discharge and meteorological conditions during validation were similar to those during the calibration period (Westhoff et al., 2011).

\subsection{Stepwise improvement of dynamic discharge simulations}

In this study, we follow a downward approach in which we stepwise improve the model (Klemeš, 1983; Jothityangkoon et al., 2001; Sivapalan et al., 2003). This means that we first model a simple case, and based on the results, we stepwise increase model complexity and develop and test new hypotheses to improve the model results. We combine this with a multi-objective model evaluation (Fenicia et al., 2008). The objective functions are (1) the Root Mean Square Error of the downstream discharge $\left(\mathrm{RMSE}_{\mathrm{Q}}\right)$, (2) the Root Mean Square Error of the in-stream temperature $\left(\mathrm{RMSE}_{\mathrm{T}}\right)$ and (3) the Root Mean Square Error of the relative contribution of the second lateral inflow at $178 \mathrm{~m}\left(\mathrm{RMSE}_{\mathrm{L}}\right)$.

For calibration, we split the observed hydrograph in two parts because different processes are responsible for the discharge peaks: the first peak is mainly caused by rain on water, while the second peak is assumed to be caused by subsurface storm flow. By first calibrating on the first discharge peak, we could test that parameter set on the second discharge peak, which allowed us to formulate different hypotheses to improve our understanding of the discharge dynamics (Sect. 3.2.2).

\subsubsection{First discharge peak}

In a first step we only focus on the first discharge peak (between 22 June 2008 20:40 and 23 June 2008 01:00 GMT+1). Here we calibrated 3 parameters. These parameters are: (1) the losses of water $\left(q_{\mathrm{L}}<0\right)$ which we describe as a function of discharge, (2) the area where saturation overland flow takes place $\left(W_{\mathrm{R}}\right)$ : this is the stream itself and its near surroundings and (3) the temperature of the rain water $\left(T_{R}\right)$. The first two influence both downstream discharge and in-stream temperature, while the third parameter only influences instream temperature.

\subsubsection{Second discharge peak}

During the second step of the calibration we focus on different processes that occur during the second discharge peak, which we assume is subsurface storm flow originating from the area upstream of the upstream V-notch weir. We first extend the simulation period of the first step with $9 \mathrm{~h}$ until 23 June 2008, 10:00 GMT+1 to cover the second discharge peak, without changing any parameters. In this run we found a couple of mismatches between observed and simulated discharge and temperature. For reasons of clarity we treat these temperature and discharge mismatches separately, although we recognize that discharge influences temperature as well. 


\section{In-stream temperature}

To improve the simulated temperature, we investigated the effect of constant and variable hyporheic exchange parameters (i.e. the flux between the stream and hyporheic zone, and volume of the hyporheic zone: both are presented per unit stream length). This results in 4 different alternatives:

1. $q_{\mathrm{hyp}}=\alpha A_{\mathrm{w}}$ and $A_{\mathrm{hz}}=P_{b} z_{\mathrm{hz}}$, where $z_{\mathrm{hz}}$ is the thickness of the hyporheic zone, and is assumed to be constant in time. For the exchange flux we used the widely used expression from Runkel (1998). For the volume of the hyporheic zone we assumed that the thickness would remain the same, and $A_{\mathrm{hz}}$ depends linearly on the wetted perimeter of the stream.

2. Both the $q_{\mathrm{hyp}}$ and $A_{\mathrm{hz}}$ are constant over time and keep the pre-event values.

3. $q_{\mathrm{hyp}}=\alpha A_{\mathrm{w}}$ and $A_{\mathrm{hz}}$ is constant over time.

4. $q_{\mathrm{hyp}}$ is constant over time and $A_{\mathrm{hz}}=P_{\mathrm{b}} z_{\mathrm{hz}}$.

\section{Discharge}

The calibrated parameter set for the first discharge peak was used for the second peak. This reference simulation resulted in a difference between simulated and observed downstream discharge for the second peak. In this step we took the difference between observed and simulated downstream discharge, and added this as a lateral inflow at distance $x_{i}$. By changing the position of this new lateral inflow, we tested 3 different hypotheses on where this water came from.

1. As a diffuse source between 250 and $350 \mathrm{~m}$. The reason for this is that when this new water is cooler than the stream water (as a first estimate we took the temperature of the third lateral inflow for the temperature of this new inflow), it would cool down the stream water, which would result in a better fit.

2. As extra water from the second lateral inflow point at $178 \mathrm{~m}$. The reason for this is that when the stream discharge is higher, the water would not heat up as rapidly. The reason for adding this new water at an already existing source is that preferential flowpaths already direct water to this point. Extra subsurface storm flow would then easily be directed to the same place.

3. As a new source at $117 \mathrm{~m}$. This source is actually a bypass or side channel, bypassing the stream between $\sim 80$ and $117 \mathrm{~m}$. It has a similar bedform as the stream, and is completely shaded by vegetation. During high (winter) flows, we have observed that part of the stream water flowed through this bypass. Here we test if this also happens during this summer rainstorm.

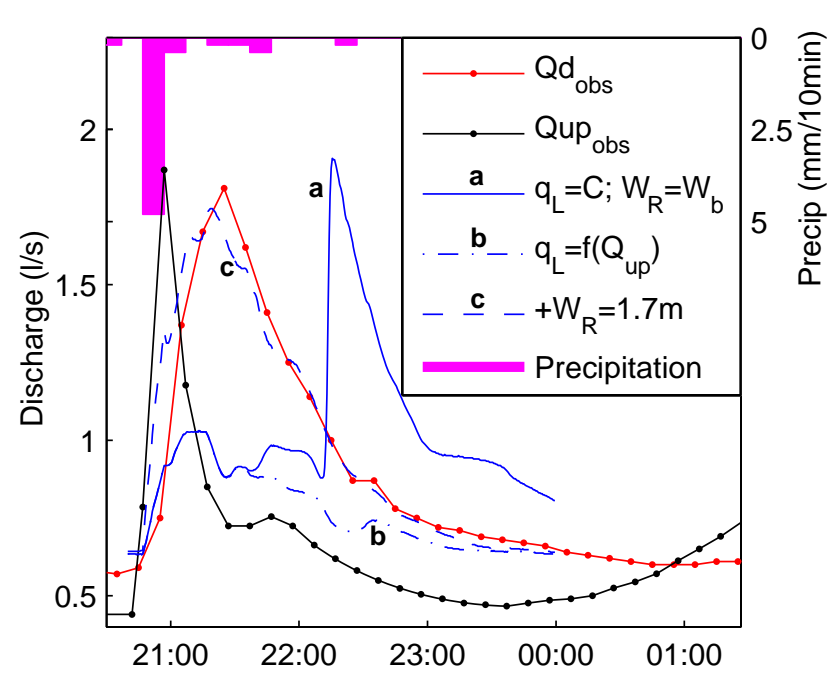

Fig. 4. Observed and simulated first discharge peak on 22 June 2008. The subscripts $d$ and up refer to downstream and upstream.

\section{Results}

Validation of the model as calibrated by Westhoff et al. (2011) was done for the period 21 June 2008, 00:00 until 22 June 2008, 20:40 GMT+1, which was just before the start of the storm event. During this validation, the 4 major lateral inflows (at 104, 178, 350 and $414 \mathrm{~m}$ from the upstream Vnotch weir, respectively) were determined to be $0.32 \pm 0.013$, $0.27 \pm 0.016,0.11 \pm 0.008$ and $0.16 \pm 0.0641 \mathrm{~s}^{-1}$, the 2 smaller inflows at 383 and $393 \mathrm{~m}$ were estimated to be 0 and $0.01 \mathrm{~s} \mathrm{~s}^{-1}$, and the 2 losses between 60 and $77 \mathrm{~m}$ and between 233 and $247 \mathrm{~m}$ were determined to be 0.41 and $0.271 \mathrm{~s}^{-1}$ to match the observed downstream discharge (Fig. 5a: blue line in bottom panel). The validation run had a $\mathrm{RMSE}_{\mathrm{T}}$ of $0.51{ }^{\circ} \mathrm{C}$. The $\mathrm{RMSE}_{\mathrm{T}}$ of the calibrated model by Westhoff et al. (2011) was $0.66^{\circ} \mathrm{C}$ for the same time span at 1 and 2 July 2009. The difference in the RMSE $E_{T}$ was mainly caused by the fact that during the calibration period the fiber optic cable was not submerged at a few distinct places. During the validation the simulated temperature downstream of $420 \mathrm{~m}$ was about $1{ }^{\circ} \mathrm{C}$ too high during the night.

\subsection{First discharge peak}

The first discharge peak was calibrated by varying the infiltration losses $\left(q_{\mathrm{L}}<0\right)$, the width accounting for "rain on water" $\left(W_{\mathrm{R}}\right)$ and the temperature of the rain $\left(T_{\mathrm{R}}\right)$. Keeping the losses constant over time and $W_{R}$ the same as the stream width $W_{\mathrm{b}}$, resulted in a simulated downstream peak discharge arriving $50 \mathrm{~min}$ too late (line $a$ in Fig. 4). Therefore we made the losses dependent on discharge (line $b$ in Fig. 4): between 233 and $247 \mathrm{~m}$ the loss was set to be $45 \%$ of the discharge at $232 \mathrm{~m}$. Between 60 and $77 \mathrm{~m}$, the loss was set to $95 \%$ during pre-event discharge $\left(0.41 \mathrm{~s}^{-1}\right)$ and 

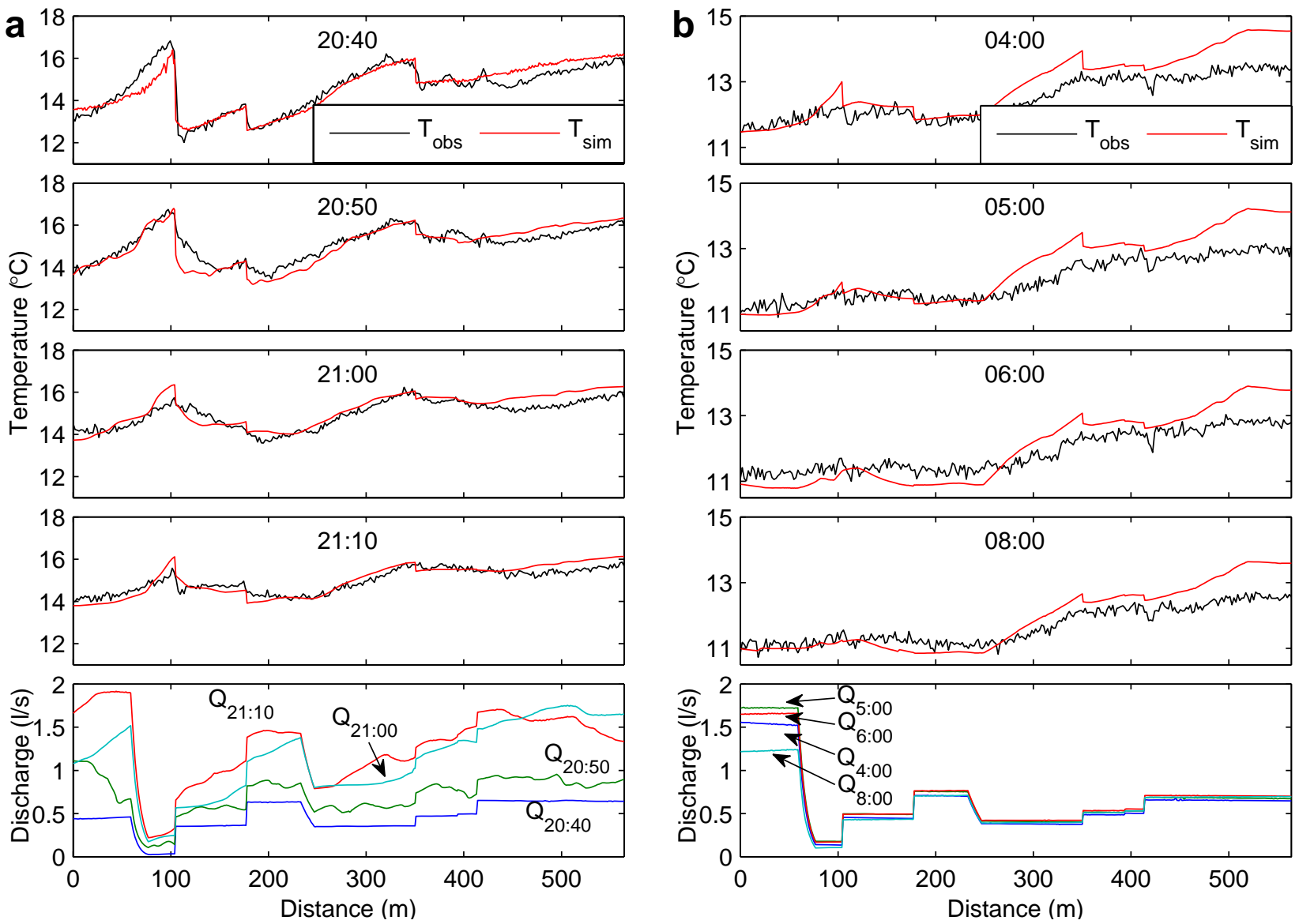

Fig. 5. Observed and simulated temperature and simulated discharge during (a) first discharge peak (after calibration) and (b) second discharge peak using the same parameters as during the first discharge peak. $q_{\mathrm{hyp}}$ and $A_{\mathrm{hz}}$ are variable over time.

$88 \%$ during peak discharge $\left(1.91 \mathrm{~s}^{-1}\right)$. To be able to simulate the observed downstream discharge peak properly, we had to change $W_{\mathrm{R}}$ to $1.7 \mathrm{~m}$ for the entire stream to account for the additional saturated overland flow. After this refinement we obtained a RMSE $\mathrm{Q}$ of $0.111 \mathrm{~s}^{-1}$ (line $c$ in Fig. 4, Table 1). Good temperature simulations were obtained when $T_{\mathrm{R}}$ was taken $2.4^{\circ} \mathrm{C}$ lower than $T_{\text {air }}$, which can be seen as a correction for the wet bulb temperature. This resulted in a $\mathrm{RMSE}_{\mathrm{T}}$ of $0.34^{\circ} \mathrm{C}$ (Fig. 5a). For an overview of all steps in the calibration process and the corresponding objection functions, see Table 1.

\subsection{Second discharge peak}

Extending the simulation period until the second discharge peak, while keeping the same parameters as during the first discharge peak, resulted in a too low downstream discharge between 03:00 and 10:00 h (Fig. 2). During the same period, the temperature between 250 and $350 \mathrm{~m}$ and downstream of $420 \mathrm{~m}$ was too high (Fig. 5b). Here, we treat both discrepancies separately.

\section{In-stream temperature}

Although we recognize that discharge influences in-stream temperature as well, we focus first on the influence of different hyporheic exchange scenarios. The 4 different scenarios tested $\left(q_{\mathrm{hyp}}=\alpha A_{\mathrm{w}}\right.$ and $A_{\mathrm{hz}}=P_{\mathrm{b}} z_{\mathrm{hz}} ; q_{\mathrm{hyp}}$ and $A_{\mathrm{hz}}$ are constant over time; $q_{\mathrm{hyp}}=\alpha A_{\mathrm{w}}$ and $A_{\mathrm{hz}}$ is constant over time; and $q_{\mathrm{hyp}}$ is constant over time and $A_{\mathrm{hz}}=P_{\mathrm{b}} z_{\mathrm{hz}}$ ), gave different results for different sections in the stream. In Fig. 6a the RMSE $\mathrm{T}_{\mathrm{T}}$ is shown for the time series between 01:00 and 10:00 $\mathrm{h}$ for each observation point (a moving average over 3 points was plotted to get slightly smoother lines). Until $250 \mathrm{~m}$ the temperature was best simulated when both the hyporheic flux and the volume of the hyporheic zone were variable over time, while downstream of $250 \mathrm{~m}$ best results were obtained when both were constant over time. From Fig. 6a, it is also seen that when only $A_{\mathrm{hz}}$ is variable while $q_{\mathrm{hyp}}$ is constant, results hardly differ from the case where both are constant over time. The difference between a constant and variable $A_{\mathrm{hz}}$ is slightly larger when $q_{\mathrm{hyp}}$ is variable. 
Table 1. Overview of calibration parameters for each step, with corresponding RMSE values.

\begin{tabular}{cccccrr}
\hline \multicolumn{6}{c}{ First discharge peak (simulations between 20:40 and 00:00h) } \\
& $q_{\mathrm{L}}<0$ & $W_{\mathrm{R}}$ & $T_{\mathrm{R}}$ & $\operatorname{RMSE}_{T}\left[{ }^{\circ} \mathrm{C}\right]$ & $\mathrm{RMSE}_{L}[\%]$ & $\mathrm{RMSE}_{Q}\left[1 \mathrm{~s}^{-1}\right]$ \\
\hline 1 & constant & $W_{\mathrm{b}}$ & $T_{\text {air }}$ & 0.38 & 8.6 & 0.45 \\
2 & $f\left(Q_{\text {up }}\right)$ & $W_{\mathrm{b}}$ & $T_{\text {air }}$ & 0.38 & 10.7 & 0.35 \\
3 & $f\left(Q_{\text {up }}\right)$ & $1.7 \mathrm{~m}$ & $T_{\text {air }}$ & 0.38 & 6.8 & 0.11 \\
4 & $f\left(Q_{\text {up }}\right)$ & $1.7 \mathrm{~m}$ & $T_{\text {air }}-2.4^{\circ} \mathrm{C}$ & 0.34 & 6.8 & 0.11 \\
\hline
\end{tabular}

Second discharge peak (simulations between 01:00 and 10:00h)

Calibration on in-stream temperature

\begin{tabular}{|c|c|c|c|c|c|}
\hline & $q_{\text {hyp }}$ & $A_{\mathrm{hz}}$ & $\mathrm{RMSE}_{T}\left[{ }^{\circ} \mathrm{C}\right]$ & $\mathrm{RMSE}_{L}[\%]$ & $\operatorname{RMSE}_{Q}\left[1 \mathrm{~s}^{-1}\right]$ \\
\hline 1 & $\alpha A_{\mathrm{W}}$ & $P_{\mathrm{b}} z_{\mathrm{hz}}$ & 0.50 & 5.8 & 0.12 \\
\hline 2 & constant & constant & 0.48 & 5.8 & 0.12 \\
\hline 3 & $\alpha A_{\mathrm{W}}$ & constant & 0.49 & 5.8 & 0.12 \\
\hline 4 & constant & $P_{\mathrm{b}} z_{\mathrm{hz}}$ & 0.49 & 5.8 & 0.12 \\
\hline \multicolumn{6}{|c|}{ Calibration on discharge } \\
\hline & & & $\operatorname{RMSE}_{T}\left[{ }^{\circ} \mathrm{C}\right]$ & $\mathrm{RMSE}_{L}[\%]$ & $\operatorname{RMSE}_{Q}\left[1 \mathrm{~s}^{-1}\right]$ \\
\hline \multirow{4}{*}{\multicolumn{3}{|c|}{$\begin{array}{l}\text { Reference* } \\
\text { Scenario 1: inflow added between } 250-350 \mathrm{~m} \\
\text { Scenario 2: inflow added at } 178 \mathrm{~m} \\
\text { Scenario 3: inflow added at } 117 \mathrm{~m}\end{array}$}} & 0.46 & 5.8 & 0.12 \\
\hline & & & 0.40 & 5.8 & 0.01 \\
\hline & & & 0.41 & 18.2 & 0.01 \\
\hline & & & 0.41 & 4.3 & 0.01 \\
\hline
\end{tabular}

${ }^{*}$ Reference refers to the simulation where $q_{\mathrm{hyp}}$ and $A_{\mathrm{hz}}$ are variable between 0 and $250 \mathrm{~m}$ and constant between 250 and $564 \mathrm{~m}$, but without the new source.

\section{Discharge}

During the second peak, the simulated downstream discharge is too low between 03:00 and 10:00 h: apparently there is some lateral inflow, which we did not account for (Fig. 2). The difference between the two hydrographs (shaded area in Fig. 2) has been added to the stream at different locations $x_{i}$, while we used the $\mathrm{RMSE}_{\mathrm{T}}$ and $\mathrm{RMSE}_{\mathrm{L}}$ to test the effect of the different locations (the $\mathrm{RMSE}_{\mathrm{Q}} \mathrm{s}$ are equal for each scenario, because the same amount of water was added for each scenario). As a reference case, we used a hyporheic exchange scenario during which $q_{\mathrm{hyp}}$ and $A_{\mathrm{hz}}$ are variable between 0 and $250 \mathrm{~m}$ while downstream of $250 \mathrm{~m}$ they are constant over time. Because the temperature downstream of $420 \mathrm{~m}$ was also too high during the validation, we only focus on the area upstream of $420 \mathrm{~m}$.

Between 117 and $260 \mathrm{~m}$, the RMSE $\mathrm{T}$ is the lowest when the new source is added at $117 \mathrm{~m}$. Between 260 and $320 \mathrm{~m}$ best results were obtained when the new source was added at $178 \mathrm{~m}$, while downstream of $320 \mathrm{~m}$ the diffuse source added between 250 and $350 \mathrm{~m}$ gave best results (Fig. 6b). Comparing the different scenarios with the observed relative contribution of the second source shows the best results when water is added at $117 \mathrm{~m}$, with a $\mathrm{RMSE}_{\mathrm{L}}$ of $4.3 \%$ for the time series between 01:00 and 10:00 h (Fig. 7, Table 1), with slightly poorer performance for the diffuse source $\left(\mathrm{RMSE}_{\mathrm{L}}\right.$ is $5.8 \%$ ). Note that the latter does not affect the second source compared to the reference simulation, since the new source was added downstream of this point. The scenario where the source was added as extra water at the second source totally mismatches the observations $\left(\mathrm{RMSE}_{\mathrm{L}}\right.$ is $18.2 \%$ ), indicating that this hypothesis should be rejected.

\section{Discussion}

\subsection{Reality check}

The presented method combines 2 sources of measured information: discharge observations and temperature observations. By combining these with a transport model for heat, we were able to investigate the spatial and temporal distribution of discharge along the whole length of the stream. In our approach we used the method as a learning tool to test, and more important, to reject hypotheses. In such a topdown approach, stepwise improvement of the model should be coupled with expert knowledge. Since a large number of different observations are needed to constrain the calibration parameters, all parameters and scenarios should be discussed for their physical meaning and realism (Seibert and McDonnell, 2002).

During the first discharge peak we calibrated 3 parameters: $W_{\mathrm{R}}, T_{\mathrm{R}}$ and stream losses. In our case study $W_{\mathrm{R}}$ has limited physical meaning, since it corrects for errors in observed rainfall and discharge. The intensive rainstorm lasted for less than $10 \mathrm{~min}$, while the logging interval of both rainfall and discharge was also $10 \mathrm{~min}$, which makes it likely 

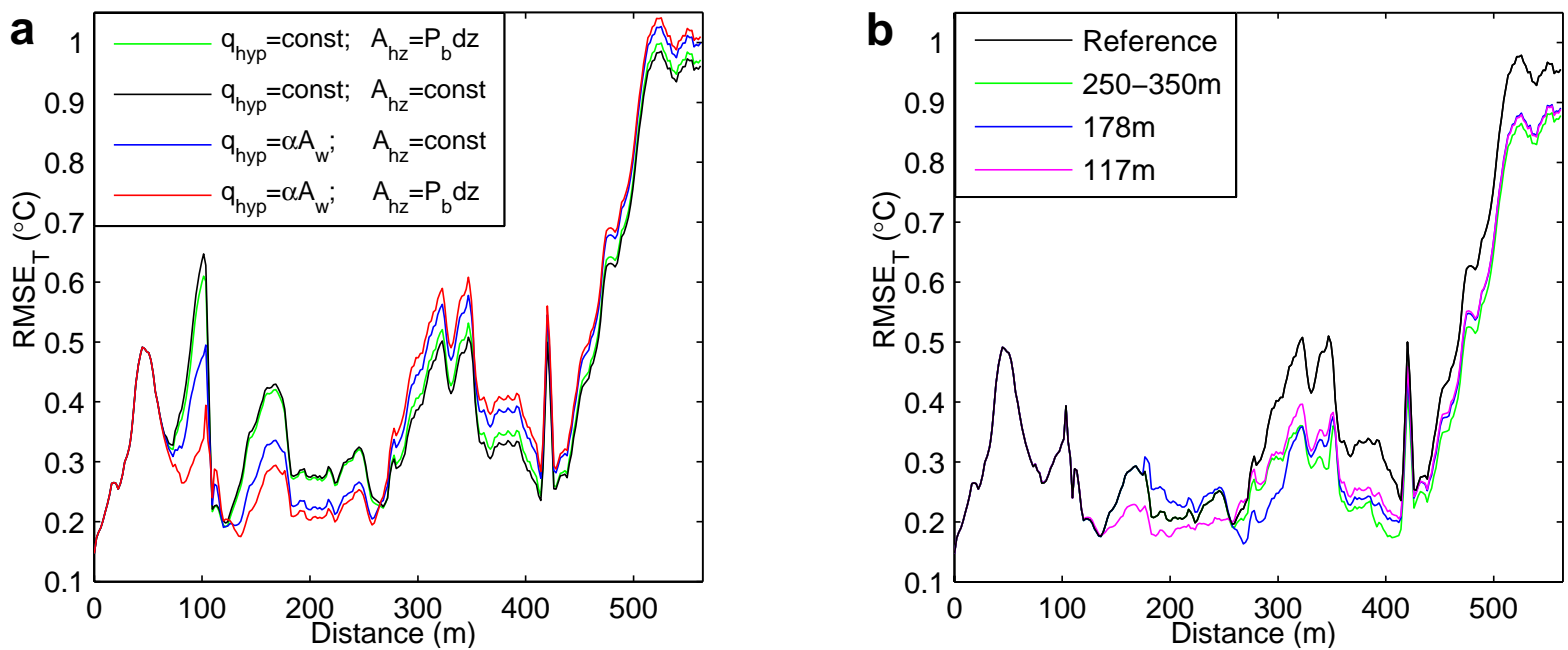

Fig. 6. RMSE $\mathrm{T}$ for (a) different hyporheic exchange scenarios, and (b) different locations of the new source. Reference refers to the simulation where $q_{\mathrm{hyp}}$ and $A_{\mathrm{hz}}$ are variable between 0 and $250 \mathrm{~m}$ and constant between 250 and $564 \mathrm{~m}$, but without the new source. The numbers of the other solutions are the location of the new source. A moving average of 3 observation point in space was taken for all time series between 23 June 2008, 01:00 and 10:00 h GMT+1.

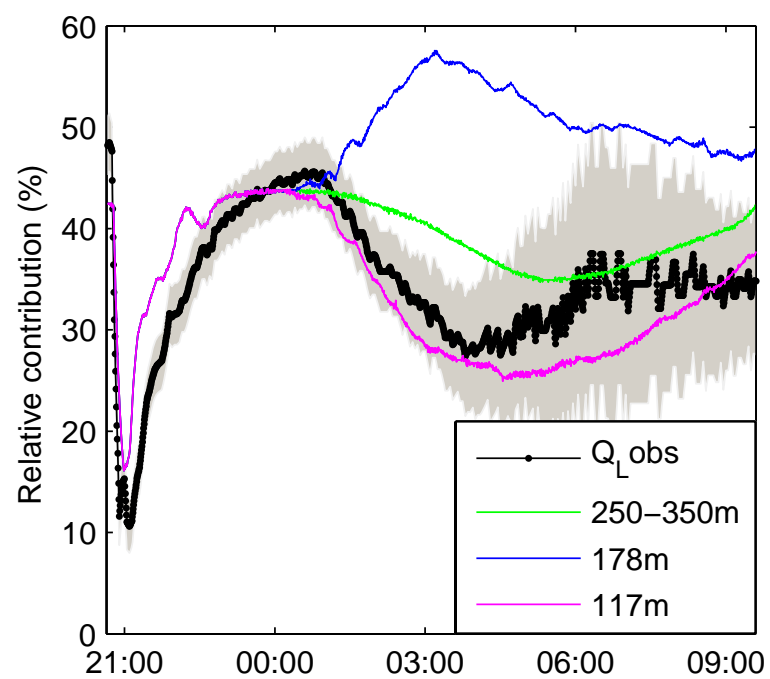

Fig. 7. Observed and simulated (3 scenarios) relative contribution of the second source. The different scenarios are the locations where the new source was added. Shaded area is observed contribution $\pm 1 \sigma$.

that observed discharged is underestimated. Because "rain on water" and saturation overland flow is the main process causing the first discharge peak, a higher $W_{R}$ could easily correct for these errors in the observations. Yet, the obtained value of $1.7 \mathrm{~m}$ seems realistic, since it is only slightly larger than the stream width itself.

The temperature of the rain $\left(T_{\mathrm{R}}\right)$ is difficult to measure. As a first estimate air temperature was taken. However, the simulated in-stream temperature appeared to be too high during and just after the rainstorm, which was the reason to decrease this temperature with $2.4^{\circ} \mathrm{C}$. This corresponds with the wet bulb temperature obtained with a relative humidity of $80 \%$, which is similar to the observed relative humidity in Ettelbruck ( $\sim 6 \mathrm{~km}$ from the site).

We conclude that infiltration losses are relative to instream discharge, while gains of water are constant over time. We explain that with the fact that the whole catchment was relatively dry during the studied period and a $6.4 \mathrm{~mm}$ rainstorm is likely not enough to increase the groundwater level or to initiate runoff from the hillslopes. Infiltration losses, on the other hand, can be large under these conditions and can vary with discharge. When the width of the stream increases, the water can infiltrate in the initially dry part of the streambed.

Figure 4, line $a$ shows that when the infiltration loss between 60 and $77 \mathrm{~m}$ is taken constant over time, the simulated peak in downstream discharge occurs $50 \mathrm{~min}$ too late. This indicates that the observed downstream discharge is not the same peak as the observed upstream peak, but that it originates from different water. This means that (1) the upstream discharge peak should disappear in-between the upstream and downstream V-notch weirs and (2) another source of water is responsible for the observed downstream discharge peak.

The second point can be easily explained by an increased amount of "rain on water": when increasing the stream width on which rain turns immediately into runoff to $1.7 \mathrm{~m}$ the observed downstream peak discharge was simulated correctly. To verify the first point, a location (or locations) has to be identified where the excess water infiltrates. The already existing infiltration loss between 60 and $77 \mathrm{~m}$ is a very likely 
place. Also because the simulated temperature anomaly caused by the lateral inflow at $104 \mathrm{~m}$ will be a factor 2 too small if the discharge peak is not reduced upstream of this point. This gives us confidence that the infiltration loss between 60 and $77 \mathrm{~m}$ is not constant but a function of stream discharge during these dry antecedent conditions.

The variability of the infiltration loss between 233 and $247 \mathrm{~m}$ is less clear. Assuming a constant loss in this reach, would result in a simulated downstream discharge peak lasting 15-20 min longer than observed, thus making the discharge peak wider. Compared to the losses between 60 and $77 \mathrm{~m}$, the infiltration losses between 233 and $247 \mathrm{~m}$ are less identifiable as the difference between simulated and observed downstream discharge are quite small. Yet, a variable loss of $45 \%$ of upstream discharge gave the best results.

The different hyporheic exchange scenarios were tested during the second discharge peak because during the first discharge peak, the different scenarios did not lead to significantly different temperatures. This could be because the discharge peak was not long enough to influence the temperature in the hyporheic zone. The different scenarios during the second peak indicate that between 0 and $250 \mathrm{~m} q_{\mathrm{hyp}}$ and $A_{\mathrm{hz}}$ are variable with varying discharge, while downstream of $250 \mathrm{~m}$ they remain constant with varying discharge (Fig. 6a). A possible explanation for this spatial variability is that between 0 and $250 \mathrm{~m}$, the width of the stream increases a lot during peak discharge: about 1.7 times during the second discharge peak and between 75 and $90 \mathrm{~m}$ the width increases to 6-10 times the original width, compared to a factor 1 to 1.3 for the area downstream of $250 \mathrm{~m}$. This results in a much higher contact area between the stream and hyporheic zone. Beside the increase in stream width, more upwelling groundwater could influence the hyporheic exchange as well (Harvey and Bencala, 1993; Harvey et al., 1996). However, as stated before, the catchment was dry, so in our case an increase in upwelling groundwater is not so likely.

The main objective of this study was to see where and when discharge was generated. Here we tested 3 hypotheses about the location of the missing water to close the water balance. The tested locations were chosen after the first results of the reference simulation of the second peak. In principle, each location could be tested, but with knowledge of the field site, only 3 locations were considered feasible. The location of the diffuse source $(250-350 \mathrm{~m})$ was chosen, since it directly influence the in-stream temperature at this location. However, because the catchment was relatively dry and the the rainstorm small, this hypothesis is not so likely. The hypothesis of an increase of the excisting source at 178 $\mathrm{m}$ seems realistic, since only some extra water is needed to increase the lateral inflow. However, our model results (especially expressed in $\mathrm{RMSE}_{\mathrm{L}}$ and Fig. 7) gave reasons to reject this hypothesis.

In the third scenario, we hypothesized that a bypass becomes active during the second discharge peak. An active bypass was observed during higher flows, and therefore it is likely that it happened during this event as well. It also means that a significant amount of water that we accounted for as infiltration loss between 60 and $77 \mathrm{~m}$, filled the dry bypass, and only when the whole bypass was saturated, it connected to the stream again. The initial wetting up of the bypass would also explain the time lag between the first discharge peak and the activation of the bypass. Overall, the third scenario seems the most likely one.

\subsection{Limitation of method}

Because temperature is used as a natural tracer, sufficient temperature fluctuations, both in space and time, are needed to be able to distinguish between different fluxes. Unfortunately, we therefore could only apply this method during a warm low flow period as we use natural heating via solar input. During winter, we observed temperature fluctuations that were too small to apply this method. Even during larger summer rainstorms, the spatial and temporal temperature fluctuations were not large enough to differentiate between different runoff fluxes. We have to conclude that during high water conditions, when subsurface storm flow becomes active and hydrologically it becomes more interesting, the method cannot rely on solar energy input, but sufficient additional energy has to be added to the stream with, for example, a powerful heat exchanger or by adding ice (we recognize that these methods also have their practical limitations). Another way would be to test this method downstream of reservoirs. For example: Toffolon et al. (2010) reported temperature increases of 3 to $4^{\circ} \mathrm{C}$ due to releases from a reservoir, with stream discharges in the order of $10 \mathrm{~m}^{3} \mathrm{~s}^{-1}$.

Another interesting question was what would happen with the hyporheic exchange during non-steady state discharge conditions. The relation between hyporheic exchange and discharge or cross-sectional area is not known a priori. For reasons of clearity, we only tested the linear relation between $q_{\text {hyp }}$ and cross-sectional area as described by Runkel (1998), versus no relation at all, while $A_{\mathrm{hz}}$ was assumed to be linearly dependent with the wetted perimeter. Although these relationships are arbitrary, it gives a first estimate of how hyporheic exchange varies with discharge.

In our case study the spatial and temporal distribution of both, hyporheic exchange and discharge had to be taken into account. In streams with limited hyporheic exchange, it is possible to focus only on the discharge distribution, making the method more reliable. The same is true when limited gains and losses are present in a stream. In such a case it may be possible to test more complex relations between hyporheic exchange and discharge.

\section{Conclusions}

In this paper we demonstrate a new method to identify spatial and temporal dynamics of in-stream discharge. We com- 
bined a routing model with an advection-dispersion model and an energy balance model, which we compared with both, discharge observations and high resolution temperature observations. This model was calibrated for steady state discharge by Westhoff et al. (2011). In the present study, it was used to unravel discharge dynamics during a small but intense summer rainstorm.

We used the model as a learning tool, where hypotheses were formulated, tested and rejected or accepted. We showed that during this rainstorm gains of water remained constant for the whole simulation period, while losses of stream water increased with increasing discharge. This resulted in large dampening of the observed upstream peak discharge. "Rain on water" and saturation overland flow in the riparian zone were likely the main processes responsible for the first discharge peak. For the second discharge peak, we conclude that most likely a bypass becomes active, which first had to be filled, before it was connected to the stream again.

Hyporheic exchange is likely to be variable with discharge in the upstream half of the stream, where the stream width increases significantly with increasing discharge, while in the downstream half temperature was better simulated if a constant hyporheic exchange was assumed.

Overall, the proposed method offers more detailed insight in spatial and temporal discharge dynamics while routing a small summer rainstorm through the stream. However, for now application of this method is limited, because a large amount of energy input is needed to create large enough temperature differences in both space and time. In our case, we used only natural temperature variations, which made this method only applicable for a small intensive summer rainstorm, during low initial discharge. To apply this method during higher discharge or less favorable meteorological circumstances, more (artificial) energy input is needed. A possible way forward may be to test this method downstream of a large dam or reservoir.

Acknowledgements. We would like to thank Guus Stelling for his help with implementing the numerical schemes and the municipality of Ettelbruck for their cooperation. We would also like to thank Anders Wörman and 2 anonymous referees for their detailed and useful comments, which improved the manuscript significantly. This research is partly funded by the Delft Cluster project Veiligheid tegen overstromingen: CT04.30.

Edited by: G. Blöschl

\section{References}

Anderson, M. G. and Burt, T. P.: The role of topography in controlling throughflow generation, Earth Surf. Proc., 3, 331-344, doi:10.1002/esp.3290030402, 1978.

Bartolino, J.: The Rio Grande - Competing demands for a desert river, Heat as a Tool for Studying the Movement of Ground Water Near Streams, edited by: Stonestrom, D. A. and Constantz, J., 816, 2003.
Becker, M. W., Georgian, T., Ambrose, H., Siniscalchi, J., and Fredrick, K.: Estimating flow and flux of ground water discharge using water temperature and velocity, J. Hydrol., 296, 221-233, doi:10.1016/j.jhydrol.2004.03.025, 2004.

Blasch, K., Constantz, J., and Stonestrom, D. A.: Thermal methods for investigation ground-water recharge, US Geological Survey Professional Paper, 1703, 353-376, 2007.

Boano, F., Revelli, R., and Ridolfi, L.: Bedform-induced hyporheic exchange with unsteady flows, Adv. Water Resour., 30, 148-156, 2007.

Bonell, M.: Selected challenges in runoff generation research in forests from the hillslope to headwater drainage basin scale, J. Am. Water Resour. As., 34, 765-785, doi:10.1111/j.17521688.1998.tb01514.x, 1998.

Constantz, J.: Interaction Between Stream Temperature, Streamflow, and Groundwater Exchanges in Alpine Streams, Water Resour. Res., 34, 1609-1615, 1998.

Constantz, J. and Thomas, C. L.: The Use of Streambed Temperature Profiles to Estimate the Depth, Duration, and Rate of Percolation Beneath Arroyos, Water Resour. Res., 32, 3597-3602, 1996.

Constantz, J., Cox, M. H., Sarma, L., and Mendez, G.: The Santa Clara River - The last natural river of Los Angeles, Heat as a Tool for Studying the Movement of Ground Water Near Streams, edited by: Stonestrom, D. A. and Constantz, J., USGS Circular, 1260, 21-27, 2003.

D'angelo, D., Webster, J., Gregory, S., and Meyer, J.: Transient storage in Appalachian and Cascade mountain streams as related to hydraulic characteristics, J. N. Am. Benthol. Soc., 223-235, 1993.

Fenicia, F., McDonnell, J. J., and Savenije, H. H. G.: Learning from model improvement: On the contribution of complementary data to process understanding, Water Resour. Res., 44, W06419, 10.1029/2007WR006386, 2008.

Gomi, T., Sidle, R. C., Miyata, S., Kosugi, K., and Onda, Y.: Dynamic runoff connectivity of overland flow on steep forested hillslopes: Scale effects and runoff transfer, Water Resour. Res., 44, W08411, 10.1029/2007WR005894, 2008.

Ha, K., Koh, D., Yum, B., and Lee, K.: Estimation of river stage effect on groundwater level, discharge, and bank storage and its field application, Geosci. J., 12, 191-204, 2008.

Habel, F. and Bagtzoglou, A.: Wave induced flow and transport in sediment beds, J. Am. Water Resour. As., 41, 461-476, 2005.

Hart, D., Mulholland, P., Marzolf, E., DeAngelis, D., and Hendricks, S.: Relationships between hydraulic parameters in a small stream under varying flow and seasonal conditions, Hydrol. Process., 13, 1497-1510, 1999.

Harvey, J. and Bencala, K.: The effect of streambed topography on surface-subsurface water exchange in mountain catchments, Water Resour. Res., 29, 89-98, 1993.

Harvey, J., Wagner, B., and Bencala, K.: Evaluating the reliability of the stream tracer approach to characterize streamsubsurface water exchange, Water Resour. Res., 32, 2441-2451, doi:10.1029/96WR01268, 1996.

Harvey, J., Conklin, M., and Koelsch, R.: Predicting changes in hydrologic retention in an evolving semi-arid alluvial stream, Adv. Water Resour., 26, 939-950, 2003.

Hjelmfelt Jr., A. T. and Burwell, R. E.: Spatial Variability of Runoff, J. Irrig. Drain. Eng., 110, 46-54, doi:10.1061/(ASCE)0733- 
9437(1984)110:1(46), 1984.

Jothityangkoon, C., Sivapalan, M., and Farmer, D. L.: Process controls of water balance variability in a large semi-arid catchment: downward approach to hydrological model development, J. Hydrol., 254, 174-198, doi:10.1016/S0022-1694(01)00496-6, 2001.

Klemeš, V.: Conceptualization and scale in hydrology, J. Hydrol., 65, 1-23, doi:10.1016/0022-1694(83)90208-1, 1983.

Lal, A.: Modification of canal flow due to stream-aquifer interaction, J. Hydraul. Eng., 127, 567-576, 2001.

Lapham, W. W.: Use of temperature profiles beneath streams to determine rates of vertical ground-water flow and vertical hydraulic conductivity, Available from Books and Open Files Report Section USGS Box 25425, Denver, CO 80225, USGS Water-Supply Paper 2337, 1989.

Legrand-Marcq, C. and Laudelout, H.: Longitudinal dispersion in a forest stream, J. Hydrol., 78, 317-324, 1985.

Monteith, J. L.: Evaporation and surface temperature, Q. J. Roy. Meteor. Soc., 107, 1-27, 1981.

Morrice, J., Valett, H., Dahm, C., and Campana, M.: Alluvial characteristics, groundwater-surface water exchange and hydrological retention in headwater streams, Hydrol. Process., 11, 253267, 1997.

Niswonger, R. G., Prudic, D. E., Pohll, G., and Constantz, J.: Incorporating seepage losses into the unsteady streamflow equations for simulating intermittent flow along mountain front streams, Water Resour. Res., 41, W06006, 10.1029/2004WR003677, 2005.

Ragan, R. M.: An experimental investigation of partial area contributions, proc Berne Symp, Int. Assoc. Sci. Hydrol. Publ., 1968.

Retter, M., Kienzler, P., and Germann, P. F.: Vectors of subsurface stormflow in a layered hillslope during runoff initiation, Hydrol. Earth Syst. Sci., 10, 309-320, doi:10.5194/hess-10-309-2006, 2006.

Runkel, R. L.: One-dimensional transport with inflow and storage (OTIS): A solute transport model for streams and rivers, US Geological Survey Water-Resources Investigation Report, 98, 4018, 1998.

Schmid, B. H.: Can Longitudinal Solute Transport Parameters Be Transferred to Different Flow Rates?, J. Hydrol. Eng., 13, 505509, doi:10.1061/(ASCE)1084-0699(2008)13:6(505), 2008.

Schmid, B. H., Innocenti, I., and Sanfilippo, U.: Characterizing solute transport with transient storage across a range of flow rates: The evidence of repeated tracer experiments in Austrian and Italian streams, Adv. Water Resour., 33, 1340-1346, doi:10.1016/j.advwatres.2010.06.001, 2010.

Seibert, J. and McDonnell, J. J.: On the dialog between experimentalist and modeler in catchment hydrology: Use of soft data for multicriteria model calibration, Water Resour. Res., 38, 1241, doi:10.1029/2001WR000978, 2002.

Selker, J., van de Giesen, N., Westhoff, M., Luxemburg, W., and Parlange, M. B.: Fiber optics opens window on stream dynamics, Geophys. Res. Lett., 33, L24401, doi:10.1029/2006GL027979, 2006a.

Selker, J. S., Thvenaz, L., Huwald, H., Mallet, A., Luxemburg, W., van de Giesen, N., Stejskal, M., Zeman, J., Westhoff, M., and Parlange, M. B.: Distributed fiber-optic temperature sensing for hydrologic systems, Water Resour. Res., 42, W12202, doi:10.1029/2006WR005326, 2006b.
Silliman, S. E., Ramirez, J., and McCabe, R. L.: Quantifying downflow through creek sediments using temperature time series: onedimensional solution incorporating measured surface temperature, J. Hydrol., 167, 99-119, doi:10.1016/0022-1694(94)02613G, 1995.

Sivapalan, M., Blschl, G., Zhang, L., and Vertessy, R.: Downward approach to hydrological prediction, Hydrol. Process., 17, 21012111, 2003.

Sklash, M. G. and Farvolden, R. N.: The role of groundwater in storm runoff, J. Hydrol., 43, 45-65, doi:10.1016/00221694(79)90164-1, 1979.

Stallman, R. W.: Steady one-dimensional fluid flow in a semiinfinite porous medium with sinusoidal surface temperature, J. Geophys. Res., 70, 2821-2827, 1965.

Stelling, G. S. and Duinmeijer, S. P. A.: A staggered conservative scheme for every Froude number in rapidly varied shallow water flows, Int. J. Numer. Meth. Fl., 43, 1329-1354, 2003.

Taniguchi, M. and Sharma, M. L.: Solute and heat transport experiments for estimating recharge rate, J. Hydrol., 119, 57-69, doi:10.1016/0022-1694(90)90034-U, 1990.

Toffolon, M., Siviglia, A., and Zolezzi, G.: Thermal wave dynamics in rivers affected by hydropeaking, Water Resour. Res., 46, W08536, doi:10.1029/2009WR008234, 2010.

Tromp-van Meerveld, H. J. and McDonnell, J. J.: Threshold relations in subsurface stormflow: 1. A 147-storm analysis of the Panola hillslope, Water Resour. Res., 42, W02410, doi:10.1029/2004WR003778, 2006.

Tromp-van Meerveld, H. J., James, A. L., McDonnell, J. J., and Peters, N. E.: A reference data set of hillslope rainfall-runoff response, Panola Mountain Research Watershed, United States, Water Resour. Res., 44, W06502, doi:10.1029/2007WR006299, 2008.

Tyler, S. W., Selker, J. S., Hausner, M. B., Hatch, C. E., Torgersen, T., Thodal, C. E., and Schladow, S. G.: Environmental temperature sensing using Raman spectra DTS fiber-optic methods, Water Resour. Res., 45, W00D23, doi:10.1029/2008WR007052, 2009.

Uchida, T., Tromp-van Meerveld, I., and McDonnell, J. J.: The role of lateral pipe flow in hillslope runoff response: an intercomparison of non-linear hillslope response, J. Hydrol., 311, 117-133, doi:10.1016/j.jhydrol.2005.01.012, 2005.

Uhlenbrook, S. and Hoeg, S.: Quantifying uncertainties in tracerbased hydrograph separations: a case study for two-, three- and five-component hydrograph separations in a mountainous catchment, Hydrol. Process., 17, 431-453, doi:10.1002/hyp.1134, http://dx.doi.org/10.1002/hyp.1134, 2003.

Weiler, M., Naef, F., and Leibundgut, C.: Study of runoff generation on hillslopes using tracer experiments and a physically-based numerical hillslope model, IAHS Publications-Series of Proceedings and Reports-International Association of Hydrological Sciences, 248, 353-362, 1998.

Westhoff, M. C., Savenije, H. H. G., Luxemburg, W. M. J ., Stelling, G. S., van de Giesen, N. C., Selker, J. S., Pfister, L., and Uhlenbrook, S.: A distributed stream temperature model using high resolution temperature observations, Hydrol. Earth Syst. Sci., 11, 1469-1480, doi:10.5194/hess-11-1469-2007, 2007.

Westhoff, M. C., Bogaard, T. A., and Savenije, H. H. G.: Quantifying the effect of in-stream rock clasts on the retardation of heat along a stream, Adv. Water Resour., 33, 1417-1425, 
doi:10.1016/j.advwatres.2010.02.006, 2010.

Westhoff, M. C., Gooseff, M. N., Bogaard, T. A., and Savenije, H. H. G.: Quantifying hyporheic exchange at high spatial resolution using natural temperature variations along a first order stream, Water Resour. Res., under review, 2011.

Woods, R. and Rowe, L.: The changing spatial variability of subsurface flow across a hillside, J. Hydrol., New Zealand, 35, 51-86, 1996.

Wörman, A. and Wachniew, P.: Reach scale and evaluation methods as limitations for transient storage properties in streams and rivers, Water Resour. Res., 43, W10405, doi:10.1029/2006WR005808, 2007.
Wroblicky, G., Campana, M., Valett, H., and Dahm, C.: Seasonal variation in surface-subsurface water exchange and lateral hyporheic area of two stream-aquifer systems, Water Resour. Res., 34, 317-328, 1998.

Zarnetske, J. P., Gooseff, M. N., Brosten, T. R., Bradford, J. H., McNamara, J. P., and Bowden, W. B.: Transient storage as a function of geomorphology, discharge, and permafrost active layer conditions in Arctic tundra streams, Water Resour. Res., 43, W07410, doi:10.1029/2005WR004816, 2007. 